\title{
PERAN KELUARGA DAN MEDIA SOSIAL DALAM PEMBENTUKAN KARAKTER SANTUN SISWA DI SEKOLAH DASAR
}

\author{
Hidar Amaruddin ${ }^{1}$, Hamdan Tri Atmaja ${ }^{2}$, Muhammad Khafid ${ }^{3}$ \\ Pendidikan Guru Sekolah Dasar, Universitas PGRI Semarang ${ }^{1}$ \\ Pascasarjana, Universitas Negeri Semarang ${ }^{2,3}$ \\ Hidars46@gmail.com
}

\begin{abstract}
Abstrak: Banyak kasus yang menunjukkan lunturnya karakter santun di kalangan siswa di Sekolah Dasar akibat kurangnya perhatian keluarga terhadap sikap dan perilaku anak juga akibat pengaruh negatif yang ditimbulkan oleh media sosial. Tujuan penelitian ini adalah mengategorikan peran keluarga dan media sosial dalam membentuk karakter santun siswa di Sekolah Dasar serta menyanggah atau menyetujui teori habitus Pierre Bordieu. Penelitian ini menggunakan metode deskriptif dengan pendekatan kualitatif. Subjek penelitian adalah empat siswa kelas lima Sekolah Dasar Supriyadi dan Sekolah Dasar Primadana Semarang beserta orang tua mereka. Pengumpulan data menggunakan teknik wawancara, observasi, dan dokumentasi. Analisis data menggunakan teknik induktif interaktif. Hasil penelitian menunjukkan bahwa keluarga berperan dalam mendidik, mengajarkan pengetahuan, dan mengevaluasi setiap sikap dan perilaku siswa Sekolah Dasar selama ia berada di lingkup keluarga, sekolah, dan masyarakat. Sedangkan media sosial tidak berperan positif dalam pembentukan karakter santun siswa, akan tetapi justru berperan mengganggu dan merusak karakter santunnya. Oleh karena itu, keluarga harus berperan melakukan manajemen penggunaan media sosial untuk anak dalam berbagai fungsinya, seperti manajemen sebagai sarana edukasi, sarana hiburan, dan alat komunikasi untuk mempertahankan karakter santunnya.
\end{abstract}

Kata Kunci: Peran, keluarga, media sosial, karakter santun

\section{THE ROLE OF FAMILY AND SOCIAL MEDIA IN BUILDING STUDENT'S POLITE CHARACTER IN ELEMENTARY SCHOOL}

\begin{abstract}
Many cases show the declining character of politeness among students in elementary school due to the lack of family attention to their attitudes and behavior as well as the negative influence caused by social media. The purpose of this study is to categorize the role of family and social media in shaping the polite character of students in elementary schools and refuting or agreeing with habitus theory of Pierre Bordieu. This research uses a descriptive method with a qualitative approach. The research subjects were four fifth grade students of Supriyadi Elementary School and Primadana Elementary School in Semarang and their parents. Data collection uses interview, observation, and documentation techniques. Data analysis uses interactive inductive techniques. The results show that the family has a role in educating, teaching knowledge, and evaluating every attitude and behavior of elementary school students as long as he was in the scope of the family, school, and community. Whereas social media does not play a
\end{abstract}


positive role in shaping students' polite character, but instead plays a role in disrupting and damaging their polite characters. Therefore, the family must play a role in managing the use of social media for children in a variety of functions, such as management as a means of education, entertainment, and communication tools to maintain their polite character.

Keywords: Role, family, social media, polite character.

\section{PENDAHULUAN}

Perpres nomor 87 tahun 2017 tentang Penguatan Pendidikan Karakter menegaskan bahwa pendidikan karakter bertujuan untuk melindungi anak bangsa, serta mengembangkan nilai-nilai karakter luhur yang ada pada anak. Implementasi karakter luhur diperlukan untuk membentuk dan mengembangkan karakter pada anak, agar tidak hanya berhasil dalam bidang kognitif, namun juga baik dalam sikap dan berperilaku. Kurniawan (2015) menguraikan teori dari Ki Hajar Dewantara tentang "Tri Pusat Pendidikan." Tri pusat pendidikan adalah tiga pusat pendidikan yang meliputi pendidikan dalam keluarga, pendidikan di sekolah, dan pendidikan di dalam masyarakat. Keluarga adalah lembaga terkecil masyarakat yang memiliki tanggung jawab dalam mendidik anak bertujuan agar menjadikannya masyarakat yang bermoral.

Dari wawancara tidak terstruktur saat observasi awal yang dilakukan peneliti pada tanggal 3 sampai 8 Desember 2018, pada guru kelas V A dan V B SD Supriyadi dan SD Primadana Semarang, secara garis besar terungkap bahwa moral atau kesantunan siswa lambat laun kian menghilang. Melalui visi dan misinya, sekolah sudah mengupayakan untuk membentuk nilai karakter siswa dengan baik. Namun, kenyataannya seperti pada kesantunan siswa ketika berbicara, berperilaku dengan gurunya sudah tidak kelihatan adab dan sopan santunnya.

Jailani (2014) menjelaskan bahwa urgensi yang ada di keluarga yaitu menciptakan suasana dalam keluarga sebagai sarana proses pendidikan kontinu (continues progress) untuk melahirkan generasi penerus (keturunan) yang cerdas dan berakhlak (berbudi pekerti luhur), baik di mata orang tua maupun masyarakat. Jadi, penelitian yang dilakukan Syahran lebih menegaskan adanya tanggung jawab orang tua secara keseluruhan dalam keluarga. Budaya moral yang menjunjung tinggi akhlak sudah seyogyanya menjadi kebiasaan atau budaya yang ditanamkan secara kontinu di dalam keluarga pada anak sejak dini.

Seperti yang diungkapkan oleh Nur (2017) bahwa sebuah bentuk kegagalan dari keluarga ketika mengimplementasikan pendidikan karakter pada putraputrinya, akhirnya ikut mempersulit institusi atau lembaga lain di luar keluarga (sekolah, masyrakat, atau pendidikan non formal lainnya). Semua institusi ini harus berupaya memperbaiki dan membentuk nilai karakter anak secara bersama.

Sudah ada beberapa penelitian yang dilakukan dengan 
tujuan mengetahui peran keluarga terhadap perkembangan sopan santun anak (Handayani \& Munawar, 2015; Risthantri \& Sudrajat, 2015; Wahyudi \& Arsana, 2014; Widianto, 2015). Dari hasil beberapa penelitian tersebut dapat ditarik korelasi sebagai berikut, (1) peran keluarga oleh ayah/ibu dalam membentuk sopan santun anak harus dilakukan dalam suasana yang menyenangkan; (2) adanya pemberian penghargaan dan hukuman dalam membentuk sopan santun anak; (3) faktor sosial dan budaya keluarga menjadi pengaruh sopan santun anak; (4) ketaatan beribadah mampu membentuk taat perintah agama, dan karakter santun anak,

keseimbangan peran keluarga antara ayah dan ibu untuk tumbuh kembang anak; (6) harus ada keseimbangan antara karir orang tua dan pola asuh kepada anak. Perbedaan penelitian yang akan dilakukan dengan beberapa penelitian tersebut yaitu bahwa penelitian ini menekankan pada peran keluarga, sekolah, dan media sosial terhadap pembentukan karakter santun siswa.

Rithika \& Selvaraj (2013) dalam penelitian yang berjudul "Impact of social media on students academic performance" menyimpulkan bahwa ada siswa yang sangat suka menggunakan media sosial seperti facebook, twitter, dan YouTube, padahal banyak informasi palsu yang dimasukkan di media sosial tersebut. Di sisi lain juga marak kebiasaan memposting informasi yang tidak benar. Pengguna media sosial pun semakin meningkat, sehingga membuktikan bahwa media sosial kini mengambil alih dunia nyata.
Seperti yang diungkapkan oleh Elsa (2015) bahwa terlalu sering menjadikan media sosial hanya sebagai hiburan bagi anak justru banyak berakibat negatif terhadap anak.

Beberapa

penelitian dilakukan oleh Kholifah \& Naimah, (2017), Setyowati (2009), Tafricha, Suprayogi, \& Suhardiyanto (2015), dan Pradana \& Setyastama (2018) dengan tujuan untuk mengetahui urgensi dan pengaruh tata krama dan sopan santun bagi siswa. Hasil penelitian menunjukkan bahwa (1) nilai kejujuran (ojo sok milik darbeke liyan), nilai kerukunan (guyub rukun), nilai sopan santun (unggahungguh), nilai disiplin ( $k u d u$ sing wektu tentu), dan nilai kerja sama (rewang/gotong royong) sudah tertanam dengan baik pada anak. Nilai moral tersebut perlu ditanamkan terus pada anak agar anak dapat berperilaku dengan baik dan tidak melanggar aturan-aturan dan norma-norma yang ada di dalam masyarakat; (2) perilaku positif lebih ditampilkan dengan sopan santun yang dapat diimplementasikan pada cara berbicara, cara berpakaian, cara memperlakukan orang lain, dan cara mengekspresikan diri di mana pun dan kapan pun; (3) pendidikan budi pekerti dilakukan sebagai upaya pembinaan peserta didik agar menjadi orang-orang yang berwatak luhur dan berkepribadian yang terpuji sesuai dengan nilai positif, norma agama, kemasyarakatan, dan budaya bangsa. Pencerminan watak tersebut berupa religius, jujur, toleran, disiplin, bertanggung jawab, percaya diri, peka terhadap lingkungan, demokratis, cerdas, kreatif, dan inovatif; dan (4) karakter 
sopan santun ada pada tata cara berbicara dan bersikap dalam menghormati orang lain. Perbedaannya dengan penelitian yang akan dilakukan adalah bahwa dalam penelitian ini peneliti mengategorikan peran, keluarga, sekolah, dan media sosial dalam pembentukan karakter santun siswa.

Masalah pokok dalam penelitian ini adalah bagaimana keluarga dan media sosial berperan dalam pembentukan karakter kesopanan dan kesantunan siswa di sekolah. Dengan demikian, tujuan penelitian adalah menganalisis sekaligus mengategorikan peran keluarga dan media sosial terhadap pembentukan karakter kesantunan siswa di sekolah.

\section{METODE}

Penelitian ini menggunakan metode kualitatif dengan pendekatan analisis deskriptif. Subjek penelitian penelitian terdiri atas empat siswa, empat orang tua siswa kelas lima di Sekolah Dasar Supriyadi Semarang, juga empat siswa, empat orang tua siswa kelas lima di Sekolah Dasar Islam Primadana Semarang.

Teknik pengumpulan data menggunakan wawancara mendalam, observasi, dan dokumentasi. Trianggulasi digunakan untuk pemeriksaan keabsahan data. Analisis data menggunakan teknik deskriptif kualitatif model alir (flow model) dengan tahapan-tahapan: (1) reduksi data; (2) penyajian data; dan (3) penarikan simpulan.

\section{HASIL DAN PEMBAHASAN Hasil}

Setelah dikumpulkan melalui berbagai teknik pengumpulan data terhadap delapan keluarga yang putera puterinya di sekolahkan di Sekolah
Dasar Supriyadi Semarang dan Sekolah Dasar Islam Primadana Semarang, diperoleh hasil penelitian sebagai berikut.

\section{Keluarga EKB}

Di keluarga ini dapat diidentifikasi pembentukan karakter sebagai berikut. 1) Pilai-nilai agama ditanamkan dengan menggunakan analogi lingkungan sekitar dan nilai toleransi tinggi; 2) Peraturan keluarga dibuat dengan kesepakatan bersama dan bersifat luwes; 3) Cara bersosialisasi dilakukan dengan mempertimbangkan baik dan buruk sikap perilaku orang lain; 4) Protektif diri dilakukan oleh orang tua dan EKB; 5) Nilai kesantunan ditanamkan dengan mendidik kerendahan hati dengan menunduk, mencium tangan, dan cara menyapa yang sopan; 6) Nilai akhlak ditanamkan dengan menjunjung tinggi nilai humanisme, edukasi mandiri oleh EKB, evaluasi kontinu, dan tidak mengekang oleh orang tua; dan 7) Penggunaan media sosial hanya sebatas youtube parodi humor. Media sosial berperan penting untuk membentuk keberlangsungan akademik, komunikasi sebatas EKB dan orang tua, sehingga ada berbagai aspek yang mampu melahirkan karakter santun bagi EKB. Karakter santun tersebut tercipta dari nilai agama, toleransi, nilai kesantunan, nilai akhlak, edukasi mandiri, tanggung jawab, dan humanisme.

\section{Keluarga MAF}

Beberapa faktor yang dapat membentuk karakter santun MAF yaitu: 1) nilai agama (ibadah syariah), 2) peraturan keluarga yang ketat yang mendapat pengawasan 
dari kedua orang tua, 3) sopan dalam bersosialisasi, 4) nilai kesantunan dan nilai akhlak diajarkan saling melengkapi, 5) edukasi mendapat kontrol dan pengawasan langsung dari orang tua, dan 6) media sosial digunakan dengan terjadwal. Meski karakter kesantunan tercermin secara bahasa (dalam tutut kata) namun tidak berlaku untuk sikap dan perilaku MAF secara keseluruhan. Hal itu dipengaruhi oleh condongnya penggunaan media sosial sebagai hiburan yang dilakukan oleh MAF, sehingga dirinya dengan leluasa membuka konten-konten di youtube. Meski mendapat pengawasan ketat dari orang tua, MAF mampu mencari celah untuk membuka konten yang tidak sesuai dengan usianya. Konten tersebut berasal dari vlogger youtube yang bernama KIMIHIME. MAF mengakui jika tergoda untuk menonton KIMIHIME dikarenakan tampilannya yang vulgar dan memperlihatkan belahan payudara. Hal tersebut disembunyikan MAF dari orang tuanya.

\section{Keluarga FAR}

Karakter kesantunan di keluarga FAR tercipta oleh faktor-faktor berikut ini: 1) nilai agama (ibadah syariah), 2) nilai kesantunan dan akhlak, 3) sosialisasi dengan melibatkan masyarakat serta lingkungan sekitar, 4) edukasi mandiri namun terkontrol dengan pemahaman lingkungan sekitar sebagai sumber media belajar, 5) media sosial yang terjadwal dan tidak memiliki akun media sosial, 6) media sosial lebih digunakan dalam hal edukasi, dan 7) komunikasi hanya dilakukan antara FAR dan orang tuanya. Dari sini muncul indikator pembentuk karakter kesantunan FAR yang paling menonjol yaitu: nilai agama, kesantunan, humanisme yang melibatkan lingkungan sekitar, terbatasnya akses media sosial, dan condongnya penggunaan media sosial yang hanya sebatas untuk edukasi.

\section{Keluarga AZE}

Beberapa faktor yang dapat membentuk karakter kesantunan AZE yang saling berkorelasi, yaitu: 1) nilai agama mengutamakan salat lima waktu, 2) menanamkan nilai agama sebelum mengikuti pendidikan formal, 3) sosialisasi dengan rasa dan perilaku humanisme, 4) ada peraturan keluarga sebagai pembentuk budi pekerti, 5) nilai akhlak terfokus pada adab sopan santun, 6) nilai kesantunan dilakukan secara kontinu dan orang tua sebagai contoh praktis, 7) nilai-nilai agama diajarkan oleh sekolah, 8) peraturan dan kebijakan sekolah membentuk karakter kesantunan, 9) terjadwalnya penggunaan media sosial sebagai hiburan dan edukasi sebagai sarana mencari ilmu pengetahuan, dan 10) media sosial dan alat komunikasi dijadikan sebagai media untuk mengawasi anak serta menjalin kedekatan emosi antara anak dan orang tua.

\section{Keluarga JKA}

Faktor-faktor yang membentuk karakter santun JKA, yaitu: 1) nilai agama yang sudah menjadi salah satu peraturan keluarga, 2) peran ibu sebagai pemberi nasihat dan ayah sebagai pemberi teguran nada tinggi, 3) nilai humanisme dan kesantunan 
bersikap dengan cara bertukar sapa untuk menghormati, 4) sosialisasi dan protektif diri yang ketat, 5) kebijakan dan progam kesantunan dari sekolah, 6) nilai agama diberikan lengkap oleh sekolah, 7) pengawasan diberikan oleh kepala sekolah, dan 8) media sosial sebagai komunikasi tidak terlalu berpengaruh.A ada beberapa factor yang apabila dibiarkan akan mengubah karakter kesantunan JKA. Faktor tersebut antara lain perilaku imitasi yang tak terbatas. JKA tidak mampu memahami dan membedakan paras wajah "emosional" yang harus ditampilkan (condong mengikuti wajah "galak" ayahnya) dan JKA suka meniru budaya K-POP secara berlebihan hingga tidak bisa membatasi antara perilaku santun dan tidak. Jika dibiarkan, perilaku imitasi ini lambat laun menjadi kebiasaan JKA di rumah.

\section{Keluarga VLN}

Beberapa faktor dalam menentukan ketidaksantunan VLN, antara lain: 1) nilai agama dan akhlak hanya diserahkan kepada pihak sekolah dan orang tua tidak berperan penuh, 2) peraturan keluarga yang tidak mendapat sanksi tegas apabila dilanggar, 3) nilai kesantunan tidak mendapat pengawasan secara kontinu, 4) nilai akhlak hanya diajarkan lewat tayangan berita, 5) bimbingan belajar yang harus mengikuti suasana hati VLN, dan 6) penggunaan media sosial dan game online yang tidak terjadwal dan tak ada batasan. Lewat tontonan game online, VLN mengetahui omongan kasar (hal tersebut ikut disampaikan oleh ibu VLN), serta video youtube dari akun KIMIHIME yang menjadikan VLN tergoda karena tampilan yang seksi, sehingga berdampak kepada psikis dan perilaku VLN dalam memandang seorang perempuan.

\section{Keluarga LNA}

Beberapa faktor pembentuk ketidaksantunan LNA antara lain: 1) nilai agama dan akhlak yang hanya diserahkan kepada sekolah, 2) sosialisasi yang tidak ada batasan, 3) tidak ada pemahaman protektif diri dari orang tua, 4) nilai kesantunan diberikan tanpa tindak lanjut, 5) tidak adanya bimbingan belajar dari orang tua, dan 6) media sosial lebih condong digunakan sebagai praktik hiburan. Misalnya dalam konsumsi hiburan KPOP memang tidak sepenuhnya buruk terhadap LNA, namun terdapat hal-hal positif seperti arti pertemanan dan integritas anggota KPOP. Namun, apabila tidak ada batasan dalam mengaksesnya, maka tingkat kesantunan LNA akan menurun karena tingkat imitasi yang tinggi pada budaya KPOP seperti dalam hal bahasa, gaya, tarian, dan penampilan.

\section{Keluarga ALF}

Karakter santun ALF dibentuk secara ketat oleh peran dari keluarga, faktor-faktor yang membentuknya antara lain: 1) nilai-nilai agama yang mendapatkan pengawasan ketat, 2) peraturan keluarga dengan pengawasan ketat, 3) sosialisasi dan protektif diri tidak dilakukan karena orang tua meyakini anaknya sudah mengetahui baik buruk perilaku, 4) nilai akhlak ditindaklanjuti dari pihak sekolah dengan menanamkan jiwa kemanusiaan terhadap sesama, 5) mengajarkan pengetahuan dan 
bimbingan belajar yang diawasi ketat, dan 6) penggunaan media sosial yang terbatas. Namun, ada beberapa hal yang secara implisit terlihat dari perilaku ALF yang santun, yaitu keinginannya agar dia mempunyai porsi yang sama dalam penggunaan media sosial, meski hal tersebut selalu tidak diperbolehkan ibu ALF secara tegas.

\section{Pembahasan}

Habitus, Peran Keluarga, dan Media Sosial Terhadap Karakter Santun

Dara hasil penelitian yang sudah diungkapkan di atas perlu dibahas melalui pendekatan strukturalisme genetik dalam melihat perspektif dan menganalisis realitas sosial masyarakat. Rumus dari teori habitus yaitu (Habitus x Modal) + Arena $=$ Praktik. Menurut Pierre Bordieu yang diuraikan oleh Nanang Krisdinanto (2014) bahwa habitus dibentuk sekaligus membentuk struktur. Habitus memperlihatkan beberapa pembagian objektif ke dalam struktur klasterisasi seperti umur, jenis kelamin, jenis pekerjaan, komunitas/kelompok, dan kelas sosial. Habitus didapat sebagai hasil dari durasi panjangnya posisi dalam kehidupan sosial yang ditempati. Jadi, habitus itu dinamis sesuai tempat/posisi individu dalam struktur kehidupan sosial. Habitus secara sederhana bisa diartikan sebagai struktur mental atau kognitif individu dalam menghadapi kehidupan sosial. Habitus dalam penelitian ini adalah keluarga dan sekolah yang memiliki peran dalam membentuk karakter kesantunan siswa. Dengan identitas dan latar belakang keluarga (ayah dan ibu) yang berbeda-beda antara keluarga satu dengan yang lainnya, seperti karir orang tua, intelektual orang tua, pembagian peran dalam keluarga (ayah/ibu) dalam mendidik anak. Sedangkan modal sosial dalam penelitian ini adalah faktor-faktor dalam pembentuk karakter kesantunan siswa seperti nilai-nilai agama, peraturan, sosialisasi, protektif diri, nilai kesantunan, nilai akhlak, bimbingan dan arahan belajar, evaluasi, dan manajemen media sosial. Namun, modal-modal tersebut tidak secara otomatis membentuk karakter kuat dalam ranah. Ranah/arena dalam penelitian ini berkaitan erat dengan habitus, ranah/arena (lingkungan) menemukan hubungan khusus yaitu lingkup keluarga seperti ekonomi, budaya yang ada di keluarga dan sekolah. Jadi, Bordieu menghubungkan habitus dan ranah untuk menggabungkan antara subjektivitas dan objektivitas. Dengan habitus (peran dan kebijakan keluarga melalui pembiasaan) $\mathrm{x}$ modal (nilai-nilai agama-manajemen media sosial) + arena (ekonomi dan budaya keluarga dan sekolah) = praktik sosial (karakter santun siswa).

Berdasarkan uraian di atas terlihat bahwa teori habitus hanya terbukti pada 5 anak yaitu EKB, FAR, AZE, JKA, dan ALF, tetapi tidak terbukti pada 3 anak yang lain, yaitu MAF, LNA, dan VLN. Tidak terbuktinya teori habitus dikarenakan ada ruang keluarga dalam kebijakan manajemen media sosial yang tidak dilaksanakan dengan kontrol, pengawasan dan tindak lanjut, sehingga anak memiliki keleluasaan dalam membuka konten yang tidak sesuai dengan usianya. Budaya 
populer (KPOP, youtube: Vlog KIMIHIME, dan game daring) yang termuat dalam media sosial mampu mengikis karakter santun anak. Hal tersebut membuktikan bahwa media sosial tidak memiliki peran apa pun dalam membentuk karakter santun anak, justru menjadi penghambat dan merusak karakter santun yang sudah dibentuk oleh peran keluarga.

Keluarga dan sekolah memiliki ciri khas dalam membentuk karakter santun siswa Dalam habitus yang di dalamnya termuat peran, wewenang, dan kebijakan. Seperti yang diungkapkan oleh Hulukati (2015), bahwa lingkungan keluarga menjadi penanggung jawab utama terhadap pertumbuhan jasmani dan rohani anaknya yakni melalui ilmu mendidik dan membimbing putraputrinya. Berhasil tidaknya pendidikan seorang anak dapat dihubungkan dengan perkembangan sikap dan pribadi orang tuanya serta hubungan komunikasi dan role model dalam keluarganya. Keluarga mempunyai peran pertama dan paling utama untuk mendidik sikap dan perilaku anak. Bentuk dari karakter anak tergantung pada metode keluarga dalam mendidik. Wewenang dan kebijakan dibutuhkan keluarga dalam membentuk karakter kesantunan anak. Namun, tiap keluarga mempunyai latar belakang secara budaya dan ekonomi yang berbedabeda. Kebijakan keluarga yang berkarir sebagai seorang wiraswasta tentu saja berbeda dengan dosen (pendidik). Budaya (kultural) yang melekat pada keluarga dengan basis agama yang kuat tentu berbeda cara mendidiknya dengan keluarga yang tidak memiliki basis agama sama sekali.

Hal pertama yang dilakukan oleh keluarga dalam membentuk karakter kesantunan anak adalah dengan memberikannya nilai-nilai agama. Nilai agama tersebut dimaksudkan menjadi fondasi awal untuk anak dalam mengamalkan sikap dan perilaku yang luhur sesuai ajaran agama. Menurut Kusnilawati, Fauziddin, \& Astuti (2018) implementasi nilai agama dan moral adalah suatu proses edukasi berupa kegiatan atau usaha yang dilakukan dengan terstruktur dan sistematis serta harus dipertanggungjawabkan untuk memelihara, melatih, membimbing, mengarahkan, dan meningkatkan pengetahuan, kecakapan sosial, dan praktik serta sikap keagamaan pada anak yang terintegrasi (akidah, ibadah syariah dan akhlak) selanjutnya dapat diamalkan dalam kehidupan seharihari. Jadi nilai agama sudah memuat nilai budi pekerti, humanisme, dan nilai akhlak. Berangkat dari diskursus tersebut nantinya akan lahir karakter santun melalui nilai agama. Penenaman nilai agama dan juga nilai kebangsaan sangat penting artinya bagi peserta didik di sekolah (Marzuki \& Haq, 2018).

Lazarusli et al. (2014) menjelaskan bahwa keluarga berfungsi sebagai miniatur masyarakat yang menyosialisasikan nilai-nilai atau peran-peran hidup dalam masyarakat yang harus dilaksanakan oleh para anggotanya. Keluarga merupakan lembaga yang mempengaruhi perkembangan kemampuan anak untuk menaati peraturan (disiplin), mau bekerja sama dengan orang lain dan lain-lain. 
Keluarga berfungsi sebagai pelindung bagi para anggota keluarganya dari gangguan, ancaman atau kondisi yang menimbulkan ketidaknyamanan para anggotanya.

Bimbingan dan arahan belajar tentu saja menjadi salah satu pendekatan keluarga dan sekolah dalam memahami karakteristik anak. Pannilage (2017) menjelaskan bahwa kurangnya cinta dan perhatian dari orang tua untuk anak-anak adalah salah satu faktor kunci yang diidentifikasi sebagai dampak negatif pada kesejahteraan anak. Beberapa masalah yang disoroti dalam hal ini termasuk efek psikologis negatif pada anak karena tidak tersedianya ayah atau ibunya, atau keduanya dalam membimbing dan membinanya.

\section{Kebijakan dan Peran Keluarga}

Berdasarkan hasil yang diuraian di atas, diketahui peran keluarga yang pertama adalah mendidik, yakni membentuk sikap, perilaku, tutur kata, karakter religiusspiritual dan karakter luhur. Indikator mendidik antara lain: 1) penanaman nilai-nilai agama akidah, ibadah syariah, dan humanisme, 2) ada peraturan keluarga: urgensi dan kesepakatan orang tua-anak, 3) ada sosialisasi: protektif diri dan pengawasan di lingkup keluarga dan lingkungan (media sosial), 4) penanaman nilai-nilai kesantunan: salam, salim, sapa, menghormati (cium tangan, menunduk, senyum), bertutur kata dengan sopan (Jawa krama/bahasa Indonesia formal), 5) penanaman nilai-nilai akhlak: diberikan dalam mengiringi nilainilai agama yang lainnya. Nilai-nilai akhlak adalah representasi nilai agama yang menciptakan budi pekerti terhadap sesama manusia.

Sedangkan peran keluarga yang kedua adalah mengajarkan pengetahuan. Mengajarkan pengetahuan dalam arti mengajarkan dan memberikan bimbingan dalam aspek kognitif (akademik). Indikator dari mengajarkan pengetahuan antara lain dengan adanya bimbingan belajar: bimbingan belajar dilakukan oleh orang tua secara langsung. Harus ada tindak lanjut dari orang tua dalam menyikapi pengajaran dari guru kelas atau guru les. Kemudian menciptakan metode belajar untuk membuat rasa nyaman anak dalam suasana belajar. Metode belajar juga dimaksudkan untuk menghubungkan indikator mendidik (afektif dan psikomotor) dengan mengajar pengetahuan (kognitif). Metode belajar yang sesuai mampu memberikan pembelajaran bermakna (integrasi melalui kehidupan seharihari).

Peran keluarga yang terakhir adalah melakukan evaluasi. Peran keluarga dalam mengevaluasi tidak hanya difokuskan kepada prestasi belajar, tetapi juga dalam pembentukan karakter kesantunan yang menjunjung tinggi nilai akhlak dan humanisme. Evaluasi dilakukan dengan cara antara lain: 1) melakukan control, dengan mengarahkan dan menyepakati perilaku santun dan tidak santun (nasihat dan teori); 2) melakukan pengawasan, yang dilakukan dengan komprehensif (keluarga, sekolah, dan media sosial). Media sosial diawasi lewat pengecekan riwayat pencarian media sosial, dan memblokir konten yang belum sesuai dengan usianya; 3) melakukan tindak lanjut yang 
dilakukan setelah mendapatkan informasi tentang sikap dan perilaku siswa. Apakah siswa santun atau tidak santun, orang tua tetap harus melakukan tindak lanjut. Memberikan pemahaman dan praktik kesantunan dibutuhkan secara kontinu bagi siswa yang tidak santun atau bahkan yang sudah berperilaku santun sekalipun.

\section{Media Sosial Tidak Berperan Apa pun dalam Pembentukan Karakter Santun Siswa}

Agar dalam memanfaatkan media sosial proporsional dan tidak condong pada salah satu sarana pemanfaatan media sosial, maka dibutuhkan beberapa faktor dalam mengaturnya. Pembatasan yang dilakukan antara lain: 1) terjadwal, yakni penggunaan media sosial (hiburan, edukasi, komunikasi) harus terjadwal dan disepakati bersama. Apabila penggunaan media sosial berlebihan dan condong pada salah satu peran, maka akan menimbukan efek negatif seperti ketergantungan/kecanduan; pengkajian akun media sosial. Kepemilikan akun media sosial oleh siswa harus dikaji dulu tingkat kebermanfaatannya. Apabila untuk mencari inspirasi dan ilmu pengetahuan, tentu diperbolehkan. Namun, jika hanya sekadar untuk bermain dan hiburan, seyogianya tidak diperbolehkan terlebih dahulu. Akun media sosial memiliki dunia yang luas dan tak terbatas, dan daya imitasi siswa akan berdampak pada kesantunan, juga sikap dan perilaku yang lainnya.

\begin{tabular}{lrr}
\multicolumn{2}{c}{ Langkah } & pembatasan \\
selanjutnya & dengan & melakukan \\
pengecekan & riwayat & (histori
\end{tabular}

pencarian). Yang memiliki wewenang dalam pengecekan riwayat tentu saja adalah keluarga. Karena siswa sekolah dasar belum diperbolehkan membawa gawai ke sekolah. Pengecekan riwayat harus dilakukan secara kontinu setiap harinya. Meski hal ini masih punya kelemahan, misalnya riwayat bisa dihapus oleh anak secara satu per satu atau semuanya. Tidak berhenti pada pengecekan riwayat, tetapi perlu dilakukan pemblokiran atau pembatasan konten jika dibutuhkan. Hal itu berlaku pada konten di media sosial yang tidak sesuai dengan usia siswa. Kemudian langkah selanjutnya menjelaskan kepada anak bahwa edukasi media sosial bukan jalan pintas. Mesin pencari di media sosial memang canggih dan mampu menjawab persoalan apa pun, namun tetap harus ada pembatasan. Hal ini bertujuan agar siswa tidak memiliki sifat ketergantungan ketika sedang mengerjakan tugas/soal atau mencari materi ilmu pengetahuan. Sebisa mungkin siswa diarahkan untuk membaca buku terlebih dahulu, dan mesin pencari media sosial hanya sebagai penunjang, yaitu mengomparasi dan mengombinasi ilmu pengetahuan dari buku dan media sosial. Yang terakhir adalah melakukan pembatasan pada media sosial sebagai komunikasi bagi anak. Perlu dijelaskan kepada anak bahwa media sosial memang memiliki peran komunikasi yang sangat bermanfaat untuk menjalin relasi dan sosialisasi kepada orang lain. Namun, hal tersebut belum sepenuhnya dibutuhkan anak untuk berkomunikasi dengan teman sejawatnya. Karena, apabila tidak ada pengawasan lebih, maka 
komunikasi akan dimanfaatkan untuk membicarakan hal-hal yang tidak ada kaitannya dalam pendidikan.

Sementara itu Widiasworo (2019: 100) mengidentifikasi berbagai dampak negatif apabila terlalu berlebihan dalam penggunaan gawai dan media sosial (internet) oleh anak, yang antara lain: 1) risiko terkena radiasi; 2) mengakibatkan kecanduan; 3) prestasi akademik menurun; 4) merusak mental; 5) memicu pergaulan bebas; 6) tak acuh terhadap lingkungan sekitar; 7) menghabiskan banyak uang; dan 8) terjadi cyber crime dan cyber bullying. Inilah beberapa dampak negatif penggunaan media sosial yang berlebihan yang harus disampaikan guru kepada para peserta didik.

Peran media sosial yang berlebihan juga disampaikan oleh Khairuni (2016). Dalam penelitiannya diungkap dampak positif dan negatif penggunaan media yang berlebihan yang tidak seluruhnya terbukti dan berdampak langsung kepada siswa. Hal itu merunut pada temuan empirik dan teoretik bahwa jika pengasuhan dilakukan berkualitas oleh keluarga untuk membatasi akses anak dalam membuka media social, terjadwal, dan ada pengawasan terhadap riwayat media sosial, maka dampak negatif dari media social dapat diminimalkan. Meski begitu tidak dipungkiri jika peran keluarga yang terlalu memberikan porsi lebih kepada anak dalam penggunaan media sosial, akan berdampak buruk bagi anak dalam hal psikis anak. Ada berbagai macam konten di media sosial, yang mampu diimitasi anak dengan begitu mudahnya. Keluarga tidak bisa menghadapinya sendiri. Pembentuk karakter kesantunan (nilai agama-evaluasi) harus dilakukan secara komprehensif, kontinu, dan ada kontrol pengawasan yang ketat.

Konten di media sosial yang sudah mengalami akulturasi budaya yang condong ke hiburan semata, akan menghasilkan perilaku ketidaksantunan anak. Unggahungguh secara bahasa dan perilaku tidak berlaku lagi, karena tidak ditampilkan di media sosial yang sering dilihat oleh anak. Seperti yang diungkapkan oleh Ngafifi (2014) melalui penelitiannya dan oleh Fitri (2017) bahwa yang lebih mengerikan tidak hanya karakter kesantunan yang terkikis dan menghilang dari anak, namun akan berlanjut pada karakter lain yaitu, kemerosotan moral, kenakalan, penyimpangan perilaku, dan pola interaksi yang berubah menjadi acuh tak acuh terhadap lingkungan sekitar.

Menurut Akram \& Kumar (2017) ada beberapa upaya untuk mencegah dampak negatif dari peran media sosial (edukasi, hiburan, komunikasi) pada siswa. Beberapa cara tersebut antara lain: 1) melihat musik, film, acara TV, game dan selebriti yang disukai anak. Begitu diketahui apa yang menarik bagi para siswa, guru dapat melihat gambar dan pesan yang memengaruhi mereka; 2) sangat mudah bagi kaum remaja untuk menonton video YouTube pada ponsel sehingga orang tua mungkin tidak tahu siapa yang mereka tonton. Orang tua harus mencoba memantau anak-anaknya apa yang ditonton di TV atau internet dan mencoba membahas beberapa batasan dan aturan; 3) salah satu cara 
terbaik untuk membantu remaja menavigasi pengaruh pada media adalah berbicara tentang pesan. Misalnya, jika remaja menyukai gadis, orang tua dapat berbicara dengannya tentang persahabatan perempuan, pilihan hidup, harga diri, dan seks; 4) memantau pilihan remaja tidak berarti orang tua melarang anak-anaknya dari menonton media. Itu hanya membuat mereka sadar akan pengaruh negatif; 5) orang tua juga harus memilih untuk melarang beberapa aplikasi, pertunjukan, dan pertandingan. Harus dijelaskan mengapa orang tua melakukannya; dan 6) orang tua juga dapat mendorong anak-anaknya untuk menafsirkan media dengan mengajukan beberapa pertanyaan yang bisa mereka ajukan. Pilih iklan TV atau majalah dan tanyakan kepada remaja: siapa di belakangnya, apa motivasi mereka, bagaimana perasaan mereka, apa yang mereka butuhkan darinya, dan sebagainya. Orang tua dapat melakukan hal yang sama dengan panutan idola remaja. Dorong meeka untuk bertanya kepadanya mengapa mereka suka selebriti itu, apakah mereka mengikutinya dalam kehidupan nyata, apa nilai-nilai selebritas menarik bagi mereka dan sebagainya.

Hal yang paling ditakutkan dalam penggunaan media sosial terbagi menjadi dua, yaitu secara fisiologis akan mempengaruhi kesehatan siswa daan secara psikologis akan mempengaruhi tingkat imitasi siswa yang tidak terkontrol dan mengakibatkan berubahnya perilaku ke budaya populer serta menghilangkan budaya kesantunan yang telah diberikan di lingkup keluarga dan sekolah. Teori habitus tidak terbukti pada semua responden, terbukti hanya pada 5 anak dan tidak terbukti pada 3 anak lain. Adanya hal tersebut disebabkan habitus (peran keluarga dan sekolah) serta arena (ekonomi-budaya keluarga) dengan dibekali modal sosial (berupa nilai agama-evaluatif) tetap tidak mampu berdiri sendiri dalam melahirkan praktik sosial (santun) siswa. Hal ini disebabkan oleh media sosial yang seharusnya masuk di dalam habitus/pembiasaan/peran dari keluarga dan sekolah, namun dalam pelaksanaannya tidak mendapat kontrol, pengawasan dan tindak lanjut secara ketat oleh keluarga dan sekolah. Oleh karena itu, media sosial tidak memiliki peran apa pun dalam membentuk karakter santun siswa. Media sosial justru menjadi penghambat dan dapat menghilangkan karakter santun pada diri anak. Habitus mencakup tiga peran (pembiasaan dari peran keluarga dan sekolah) x modal (nilai agama-manajemen media sosial) + arena/ranah (ekonomi-budaya keluarga dan sekolah) $=$ praktik sosial (karakter santun siswa). Teori habitus akan menghasilkan praktik sosial (kesantunan) yang diharapkan apabila adanya: 1) kontrol dan bimbingan; 2) pengawasan; 3) evaluasi; dan 4) tindak lanjut. Tindak lanjut dilakukan sebagai hasil dari evaluasi sikap dan perilaku siswa (santun atau tidak santun), memperbaiki kesalahan, atau mempertahankan karakter kesantunan pada diri siswa. 


\section{SIMPULAN}

Peran keluarga terhadap karakter kesantunan siswa antara lain mendidik, mengajarkan ilmu pengetahuan, dan mengevaluasi. Ketiga indikator peran keluarga tersebut diberikan kepada siswa sejak siswa selama hidup bersama dengan keluarga. Ketiga indikator itu memiliki komponen-komponen berupa nilai-nilai dan kewajiban yang harus diimplementasikan kepada siswa untuk menciptakan karakter santun. Dalam indikator mendidik, keluarga perlu mendidik nilai-nilai agama (akidah, ibadah, dan akhlak), peraturan keluarga, sosialisasi dan protektif diri, dan nilai-nilai kesantunan. Dalam indikator mengajarkan ilmu pengetahuan, keluarga mempunyai kewajiban untuk memberikan waktu luang, membimbing, dan mengarahkan siswa dalam memahami proses belajar. Dalam indikator mengevaluasi, keluarga mempunyai kewajiban untuk mengevaluasi sikap dan perilaku siswa di lingkup keluarga, sekolah, tetangga, dan media sosial. Orang tua (ayah dan ibu) menjadi pihak yang melaksanakan peran secara teoretis (nasihat) dan praktik (figur contoh) bagi siswa.

Media sosial tidak memiliki peran dalam membentuk karakter santun siswa, justru media sosial menjadi penghambat dan dapat merusak karakter santun yang sudah terbentuk dalam diri siswa. Media sosial masuk dalam peran keluarga, yaitu peran keluarga dalam kebijakan dan manajemen media sosial untuk membentuk karakter santun siswa. Manajemen media sosial dilakukan agar penggunaan media sosial tidak menjadi penghambat bagi keluarga dan sekolah dalam membentuk karakter santun siswa. Media sosial yang sering digunakan oleh siswa sebagai hiburan yaitu, youtube (KIMI HIME, Vlogger parodi, $\mathrm{KPOP}$ ), instagram, dan game online (PUBG dan Mobile Legend). Media sosial sebagai edukasi yaitu mesin pencari google (blog, kaskus, wordpress, dan brainly). Serta media sosial sebagai komunikasi (Whatsapp). Ketiga indikator dalam pemanfaatan media sosial harus dibatasi dan terjadwal, serta memperoleh kontrol, pengawasan, dan tindak lanjut oleh keluarga dengan cara mengecek histori dan memberikan jadwal, serta peran sekolah dengan menanamkan konsep kesantunan sebagai dasar sikap dan perilaku siswa.

Peran media sosial menjadi peran ketiga setelah keluarga dan sekolah, karena era digital telah menggeser peran lingkup tetangga menjadi peran media sosial. Jika media sosial digunakan berlebihan, maka akan berdampak buruk secara fisiologis dan psikologis kepada siswa. Dampak buruk fisiologis yaitu mampu mempengaruhi kesehatan fisik siswa, dan dampak psikologisnya berupa tingkat imitasi siswa yang tinggi, sehingga karater kesantunan akan terkikis dan menghilang dalam diri siswa. Meskipun karakter kesantunan sudah dibentuk oleh keluarga dan sekolah, namun penggunaan media sosial berlebihan dapat menghilangkan karakter kesantunan siswa dan digantikan oleh budaya-budaya popular, seperti KPOP, game online, dan parodi. 


\section{UCAPAN TERIMA KASIH}

Terima kasih saya ucapkan kepada Dr. Muhammad Khafid, M.Si., selaku pembimbing I, dan Dr. Hamdan Tri Atmaja, M.Pd., selaku pembimbing II. Atas arahan dan bimbingan beliau, serta Prof. Joko Sutarto, M.Pd., yang telah menguji secara ilmiah penelitian saya, sehingga saya bisa menyelesaikan penelitian ini. Terima kasih juga disampaikan kepada ketua dewan redaksi Jurnal Pendidikan Karakter yang telah melakukan review dan pengeditan hingga artikel ini layak dimuat.

\section{DAFTAR PUSTAKA}

Akram, W. \& Kumar, R. (2017). A Study on positive and negative effects of social media on society. International Journal of Computer and Engineering. 5(10): 2347-2693. DOI: $10.26438 / \mathrm{ijcse} / \mathrm{v} 5 \mathrm{i} 10.351$ $\underline{354}$

Fitri, S. (2017). Dampak positif dan negatif sosial media terhadap perubahan sosial anak. Naturalistic: Jurnal Kajian Penelitian dan Pembelajaran. 1(2): 118-123. DOI: $\underline{10.35568 / \text { naturalistic.v1i2.5. }}$.

Handayani, A. \& Munawar, M. (2015). Work-family balance and quality of parenting in optimizing children development. Indonesian Journal of Early Childhood Education Studies. 4(1): 11-18. DOI: 10.15294/IJECES.V4I1.9 $\underline{447}$.
Hulukati, W. (2015). Peran lingkungan keluarga terhadap perkembangan anak. MUSAWA. 7(2): 265-282. Retrieved from https://www.neliti.com/publica tions/114008/peranlingkungan-keluarga-terhadapperkembangan-anak.

Jailani, M.S. (2014). Teori pendidikan keluarga dan tanggung jawab orang tua dalam pendidikan anak usia dini. NADWA: Jurnal Pendidikan Islam. 8(2): 245260.

DOI: 10.21580/nw.2014.8.2.580.

Khairuni, N. (2016). Dampak positif dan negatif sosial media terhadap pendidikan akhlak anak. Jurnal Edukasi. 2(1): 91106.

DOI: 10.22373/je.v2i1.693.

Kholifah, K. \& Naimah, T. (2017). Studi tentang sopan santun pada peserta didik. Jurnal Sains dan Humaniora. 1(1): 19.

DOI: $\underline{10.30595 / j s s h . v 1 i 1.1036 .}$

Krisdinanto, N. (2014). Pierre Bourdieu Sang Juru Damai. KANAL: Jurnal Ilmu Komunikasi. 2(2): 189-206. DOI: $10.21070 / \mathrm{kanal.v2i2.300.}$

Kurniawan, M.I. (2015). Tri pusat pendidikan sebagai sarana pendidikan karakter anak sekolah dasar. Jurnal Pedagogia. 4(1): 41-49. DOI: $10.21070 /$ pedagogia.v4i1 .71 . 
Kusnilawati, Fauziddin, M. \& Astuti. (2018). Meningkatkan aspek perkembangan nilai agama dan moral anak usia dini dengan penerapan metode bercerita tema Islami. Aulad: Journal on Early Childhood. 1(1), 28-38. DOI: $10.31004 /$ aulad.v1i1.4.

Lazarusli, B., Lestari, S., Abdullah, G., Sudrajat, R. \& Suciptaningsih, O.A. (2014). Penguatan peran keluarga dalam pembentukan kepribadian anak melalui seminar dan pendampingan masalah keluarga. E-DIMAS: Jurnal Pengabdian Masyarakat. 5(1): 1-12. DOI: $10.26877 / \mathrm{e}-$ dimas.v5i1.565.

Marzuki, M. \& Haq, P.I.(2018). Penanaman nilai-nilai karakter religius dan karakter kebangsaan di Madrasah Tsanawiyah Al Falah Jatinangor Sumedang, 8(1), 8494.

DOI: https://doi.org/10.21831/j pk.v8i1.21677.

Ngafifi, M.. (2014). Kemajuan teknologi dan pola hidup manusia dalam perspektif sosial budaya. Jurnal Pembangunan Pendidikan. 2(1): $\quad 33-47$. DOI: $\underline{10.21831 / j p p f a . v 2 \mathrm{i} 1.2616}$

Pradana, C.S. \& Setyastama, R.. (2018) Pendidikan tata krama dan sopan santun dalam pertunjukan tari klasik gaya Yogyakarta di Bangsal
Srimanganti Keraton

Yogyakarta. Jurnal Gama Societa. 1(1): 53-59. DOI: 10.22146/jgs.34049.

Rhisthantri, P., \& Sudrajat, A.. (2015). Hubungan antara pola asuh orang tua dan ketaatan beribadah dengan perilaku sopan santun peserta didik. Harmoni Sosial: Jurnal Pendidikan IPS. 2(2): 191-202. DOI: $\underline{10.21831 / \mathrm{hsjpi} . v 2 \mathrm{i} 2.7670}$

Rithika M. \& Selvaraj, S. (2013). Impact of social media on student's academic performance. International Journal of Logistics \& Supply Chain Management Perspectives, 2(4): 636-640. Retrieved from https://www.researchgate.net/p rofile/Sara_Selvaraj3/publicati on/288516435 IMPACT OF SOCIAL_MEDIA_ON_STUD ENT'S_ACADEMIC_PERFO RMANCE/links/5681daf608ae 1975838f964f.pdf.

Setyowati, E. (2009). Pendidikan budi pekerti menjadi mata pelajaran di sekolah. Lembaran Ilmu Kependidikan. 38(2): 148154. Retrieved from https://journal.unnes.ac.id/nju/i ndex.php/LIK/article/view/487.

Tafricha, A.N., Suprayogi \& Suhardiyanto, A. (2015). Penanaman nilai-moral anak dalam keluarga samin (sedulur sikep) kabupaten Blora. Unnes Civic Education Journal. 1(2): 1-12. Retrieved from https://journal.unnes.ac.id/sju/i 
ndex.php/ucej/article/view/100 $8 / 0$.

Upali, P. (2017). Impact of family on children's wellbeing. Journal of Sociology and Social Work. 5(1): 149-158. DOI: 10.15640/jssw.v5n1a15.

Wahyudi, D \& Arsana, I.M. (2014). Peran keluarga dalam membina sopan santun anak di Desa Galis Kecamatan Galis Kabupaten Pamekasan. Kajian Moral dan Kewarganegaraan. 1(2): 290-304. Retrieved from https://jurnalmahasiswa.unesa. ac.id/index.php/jurnal- pendidikan-

kewarganegaraa/article/view/6 706.

Widianto, E. (2015). Peran orang tua dalam meningkatkan pendidikan karakter anak usia dini dalam keluarga. Jurnal PG-PAUD Trunojoyo, 2(1): 31-39. Retrieved from http://journal.trunojoyo.ac.id/p gpaudtrunojoyo/article/view/18 17.

Widiasworo, E. (2019). Guru Ideal di Era Digital. Yogyakarta: Noktah. 